\title{
Temperature and sunlight controls of mercury oxidation and deposition atop the Greenland ice sheet
}

\author{
S. Brooks ${ }^{1}$, C. Moore ${ }^{2}$, D. Lew ${ }^{1}$, B. Lefer ${ }^{3}$, G. Huey ${ }^{4}$, and D. Tanner ${ }^{4}$ \\ ${ }^{1}$ NOAA ATDD, 456 S. Illinois Ave, P.O. Box 2456, Oak Ridge, TN 38731, USA \\ ${ }^{2}$ University of Maryland, Center for Environmental Science, Appalachian Laboratory, Frostburg, MD 21532, USA \\ ${ }^{3}$ Dept. of Earth and Atmospheric Sciences, Univ. of Houston, 312 Science \& Research Building 1, Houston, TX 77204, USA \\ ${ }^{4}$ Georgia Institute of Technology, School of Earth \& Atmospheric Sciences, Atlanta, GA 30332, USA
}

Received: 28 December 2010 - Published in Atmos. Chem. Phys. Discuss.: 1 February 2011

Revised: 28 July 2011 - Accepted: 29 July 2011 - Published: 15 August 2011

\begin{abstract}
We conducted the first ever mercury speciation measurements atop the Greenland ice sheet at Summit Station (Latitude $72.6^{\circ} \mathrm{N}$, Longitude $38.5^{\circ} \mathrm{W}$, Altitude $3200 \mathrm{~m}$ ) in the Spring and Summer of 2007 and 2008. These measurements were part of the collaborative Greenland Summit Halogen- $\mathrm{HO}_{\mathrm{x}}$ experiment (GSHOX) campaigns investigating the importance of halogen chemistry in this remote environment. Significant levels of $\mathrm{BrO}(1-5$ pptv) in the near surface air were often accompanied by diurnal dips in gaseous elemental mercury (GEM), and in-situ production of reactive gaseous mercury (RGM). While halogen (i.e. Br) chemistry is normally associated with marine boundary layers, at Summit, Greenland, far from any marine source, we have conclusively detected bromine and mercury chemistry in the near surface air. The likely fate of the formed mercurybromine radical $(\mathrm{HgBr})$ is further oxidation to stable RGM $\left(\mathrm{HgBr}_{2}, \mathrm{HgBrOH}, \mathrm{HgBrCl} \ldots\right)$, or thermal decomposition. These fates appear to be controlled by the availability of $\mathrm{Br}$, $\mathrm{OH}, \mathrm{Cl}$, etc. to produce $\mathrm{RGM}(\mathrm{Hg}(\mathrm{II}))$, versus the lifetime of $\mathrm{HgBr}$ by thermal dissociation. At Summit, the production of RGM appears to require a sun elevation angle of $>5$ degrees, and an air temperature of $<-15^{\circ} \mathrm{C}$. Possibly the availability of $\mathrm{Br}$, controlled by photolysis $\mathrm{J}\left(\mathrm{Br}_{2}\right)$, requires a sun angle $>5$ degrees, while the formation of RGM from $\mathrm{HgBr}$ requires a temperature $<-15^{\circ} \mathrm{C}$. A portion of the deposited RGM is readily photoreduced and re-emitted to the air as GEM. However, a very small fraction becomes buried at depth. Extrapolating core samples from Summit to the
\end{abstract}

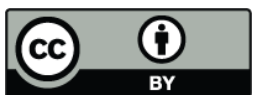

Correspondence to: S. Brooks (steve.brooks@noaa.gov) entire Greenland ice sheet, we calculate an estimated net annual sequestration of $\sim 13$ metric tons $\mathrm{Hg}$ per year, buried long-term under the sunlit photoreduction zone.

\section{Introduction}

In Spring 2007 and again in Spring/Summer 2008 we conducted the first ever mercury speciation measurements atop the Greenland ice sheet at Summit Station $\left(72.6^{\circ} \mathrm{N}, 38.5^{\circ} \mathrm{W}\right.$, Altitude $3200 \mathrm{~m}$ ). These measurements were part of the larger GSHOX campaigns investigating the importance of halogens in this remote environment. Significant levels of $\mathrm{BrO}(1-5 \mathrm{pptv})$ were observed in the near surface air utilizing both a differential optical absorption spectrometer (DOAS; Stutz et al., 2011) and a chemical ionization mass spectrometer (CIMS; Liao et al., 2011). The presence of $\mathrm{Br}$ chemistry in the near surface air was most often accompanied by a dip in gaseous elemental mercury (GEM) concentrations, and simultaneous in-situ production of reactive gaseous mercury (RGM). This conversion of GEM to RGM in the near surface air has been found to be common during cold $\left(<\sim 0^{\circ} \mathrm{C}\right)$, sunlit times at polar coastal and marine locations (Steffen et al., 2008). Here we report the first $\mathrm{Hg}$ speciation measurements to demonstrate that significant GEM to RGM atmospheric chemistry occurs at the top of the Greenland ice sheet, nearly $1000 \mathrm{~km}$ from the nearest marine environment.

Summit is a remote camp several hundreds of kilometers from any population or infrastructure. Mercury emissions from the main station itself were not detected, as evidenced by no statistical differences in $\mathrm{Hg}$ concentrations when our site was downwind of the main camp. All

Published by Copernicus Publications on behalf of the European Geosciences Union. 
atmospheric sampling was conducted in the clean air sector at an all-electric satellite camp located roughly $1.5 \mathrm{~km}$ SouthSouthwest of the main Summit station. Wind direction at Summit is seldom from the North, placing our atmospheric sampling predominantly on the upwind side of main station.

Previous atmospheric chemistry investigations at Summit (Sjostedt et al., 2007) had hinted at active bromine chemistry, but showed no direct evidence and speculative mechanisms for $\mathrm{Br}$ transport to Summit. Here we confirm active $\mathrm{Br}+\mathrm{Hg}$ chemistry at Summit, although the specific pathway(s) for $\mathrm{Br}$ transport to the site are yet to be fully understood.

\subsection{Prior polar mercury measurements}

The initial discovery of Arctic mercury chemistry in the near surface air was made in Alert, Canada in 1995 (Schroeder et al., 1998). It was shown that GEM was oxidized and deposited onto Arctic snow surfaces more rapidly than was previously thought possible. In recent years, this chemistry has been observed at a variety of polar coastal sites including Barrow, Alaska (Lindberg et al., 2002), Neumeyer, Antartica (Ebinghaus et al., 2002), Ny-Alesund, Svalbard (Berg et al., 2003), Station Nord, Greenland (Skov et al., 2004), and Amderma, Russia (Steffen et al., 2005). More recently Brooks et al. (2008) and Dommergue et al. (2010) reported RGM production and deposition atop the Antarctic ice sheet at South Pole and the French-Italian Concordia Base, respectively.

Previously at Summit, Greenland, Faïn et al. (2008) measured snowpack GEM in the interstitial air from the surface to a depth of $30 \mathrm{~m}$. They reported photolytic production and destruction of GEM close to the snow surface during summer, and dark oxidation of GEM up to $270 \mathrm{~cm}$ depth. From measurements conducted in June 2006 they reported photochemical transformation of gaseous elemental mercury which resulted in diel variations in the concentrations of GEM in the near-surface interstitial air.

In general, it has been determined that polar mercury chemistry results from GEM oxidation by halogens (Steffen et al., 2008), and is confined to the shallow atmospheric boundary layer (typically less then a few hundreds of meters; Banic et al., 2003; Tackett et al., 2007; Mao et al., 2010). RGM production and deposition is considered the predominant pathway for mercury deposition to the polar regions as GEM itself does not condense or significantly dry deposit (dry deposit is very slow), and is not significantly adsorbed onto snow and ice surfaces (Lindberg et al., 2002; BartelsRauch et al., 2002; Ferrari et al., 2004). RGM deposition can dramatically increase mercury concentrations in the surface snow up to $500 \mathrm{ng}^{-1}$ (Lindberg et al., 2002; Lu et al., 2001; Brooks et al., 2006). However, it has also been observed that, within hours of deposition under sunlit conditions, the majority of the deposited $\mathrm{Hg}$ is photoreduced and re-emitted as GEM back to the atmosphere (Lalonde et al., 2002, 2003; Dommergue et al., 2003). Net deposition relies on mercury-rich snow becoming buried below the sunlit layer ( $\sim 10 \mathrm{~cm}$; King and Simpson, 2001$)$ by drifts or additional snowfall (Brooks et al., 2008). Determinations of net deposition to the Arctic are therefore difficult. Current estimates by Holmes et al. (2010) and Ariya et al. (2004) are 60 and 300 metric tons Hg per year, respectively. The observations reported here, indicating that $\mathrm{Hg}$ chemistry and deposition occur atop the Greenland ice sheet, will upwardly revise these estimates for the Arctic by $\sim 4-20 \%$.

\subsection{Implications}

Increasingly, ice cores from Greenland and Antarctica are being used to elucidate the atmospheric and climate history of this planet. While mercury data from the ice sheet corings are sparse, pre-industrial mercury net deposition from ice coring, covering the past $34000 \mathrm{yr}$, show that mercury deposition was highest during the last glacial maximum (Vandal et al., 1993). Post-industrial ice coring in Greenland, showing mercury deposition from 1949 to 1989, indicates higher net deposition rates in the 1950's and 1960's followed by a decrease in recent years (Boutron et al., 1998; Mann et al., 2005). These higher levels in the 1950's and 1960's, followed by steadily decreasing levels, roughly correlate with the anthropogenic emissions trend in the Northern Hemisphere. By understanding current $\mathrm{Hg}$ chemistry, deposition and burial, it may be possible that $\mathrm{Hg}$ recovered from Greenland ice cores along with other species, may indicate past gaseous elemental mercury concentrations, snow burial rates, and/or halogen chemistry levels.

\subsection{Measured mercury species}

The three measured atmospheric mercury species are: (1) gaseous elemental mercury (GEM) or $\mathrm{Hg}(0)$; (2) reactive gaseous mercury (RGM) or Hg (II,g); and (3) particle-bound $\mathrm{Hg}$ (II or I,s) mercury, which we measured only the fine particulate mercury fraction (FPM, $\mathrm{PM}_{2.5}$ ). At present, RGM and FPM, being without standards, are merely operationally defined.

GEM has an average atmospheric lifetime of a few months (Holmes et al., 2006) which permits some mixing at the hemispheric scale, with northern hemispheric ambient levels of $\sim 1.5 \mathrm{ng} \mathrm{m}^{-3}$. GEM is relatively insoluble, and therefore is not wet deposited, and near-surface atmospheric concentrations are unaffected by snow or fog events. GEM comprises $\sim 97 \%$ of the total atmospheric mercury in the lower troposphere (e.g. Slemr et al., 2003) and has many natural and anthropogenic sources (volcanoes, enriched soils, coal combustion, biomass burning etc.). However, none of these sources are present in central Greenland.

RGM is operationally defined as mercury collected by a $\mathrm{KCl}$ coated denuder tube (Steffen et al., 2008). RGM is typically believed to be dominated by $\mathrm{Hg}$ (II) such as $\mathrm{HgCl}_{2}, \mathrm{Hg}$ ClX and $\mathrm{HgBrX}$ (Landis et al., 2002; Goodsite et al., 2004). RGM is typically rare in the lower troposphere, $\sim 1-2 \mathrm{pg} \mathrm{m}^{-3}$ 
(sub-parts per trillion levels), comprising just $\sim 1 \%$ of atmospheric mercury in the lower troposphere (Lindberg et al., 2002, 2007). RGM is water soluble, has a high dry deposition rate and so is rapidly removed from the near-surface air (lifetime in the near-surface air is typically just hours; Skov et al., 2006). With the exception of active volcanoes, RGM has negligible natural surface sources and is primarily emitted by coal combustion, cement manufacturing, and industrial processes (all absent in central Greenland; UNEP, 2002). RGM can also be produced in-situ by the atmospheric oxidation of gaseous elemental mercury (Lindberg et al., 2002). RGM has the potential to convert to FPM in the presence of sea salts and other aerosols.

FPM is comprised of oxidized mercury bound to fine $\left(\mathrm{PM}_{2.5}\right)$ particles. FPM has a low, but significant, dry deposition rate, and in the absence of precipitation, a significant lifetime in the near-surface air (1-2 days; UNEP, 2002; Lindberg et al., 2007). FPM is the least studied and least measured form of atmospheric mercury. FPM has low concentrations $\left(\sim 1-5 \mathrm{pg} \mathrm{m}^{-3}\right)$ in the near surface air, but is more common near the tropopause (Murphy et al., 1998).

\section{Measurements}

Our mercury speciation sensor suite consisted of Tekran models $2537 \mathrm{a} / 1130 / 1135$ for the determination of gaseous elemental mercury $\left(\mathrm{GEM}, \mathrm{Hg}^{\circ}\right)$, reactive gaseous mercury (RGM, $\mathrm{Hg}(\mathrm{II}, \mathrm{g})$ ), and fine particulate mercury (FPM, $\mathrm{Hg}(\mathrm{II}, \mathrm{p})$ ), respectively (Fitzgerald and Gill, 1979; Lu et al., 1998; Landis et al., 2002).

The system was set to collect RGM and FPM for one hour, while concurrently collecting and analyzing $5 \mathrm{~min}$ GEM samples. At the end of the sampling hour, the system analyzed the preconcentrated RGM and FPM over the following hour. The resultant dataset consists of 12 one-hour RGM and FPM samples daily, and the same $12 \mathrm{~h}$ of $5 \mathrm{~min}$ GEM samples. Effectively, the sampling system runs $50 \%$ of the time and analyzes, without sampling, $50 \%$ of the time. Therefore, not all short duration (minutes to one hour) mercury events are captured.

Inlet air to the Tekran 1130 pump unit was pre-conditioned with a Tekran model 1102 air drier. The system was placed $\sim 3 \mathrm{~m}$ South-Southwest of a small shelter at the satellite camp, with the inlet $\sim 1.3 \mathrm{~m}$ above the surface. At this height the inlet was sufficiently above the blowing snow layer, but in the lowest few percent of the atmospheric boundary layer, which was often as shallow as a few tens of meters.

Specific care was taken for the cold, high-altitude environment. The case heaters for the 1130 and 1135 front end units were increased from 100 (standard) to 200 watts. Additional foam insulation was used to cover the bottom vented plate in the 1135 front end unit, and the side vent of the 1130 front end unit. These were done to minimize the variation in interior temperatures regardless of wind and weather con- ditions. Likewise, the heated sample lines were kept fully external to the climate controlled shelter. Otherwise, temperature changes between interior and exterior portions would induce hot/cold zones and mercury absorption/desorption at the tubing walls. To compensate for the high altitude of Summit, we reduced the mass flow through the 1130 and 1135 front end units to retain the $\sim 0.1$ second designed residency time for ambient air over the $\mathrm{KCl}$-coated annular denuder. The glassware in the front end units was switched weekly.

Surface snow was collected every other day throughout the 2007 and 2008 campaigns. All snow samples were collected from the top $3-5 \mathrm{~cm}$ in pre-cleaned $40 \mathrm{ml}$ I-chem bottles using clean techniques. A single core was obtained in 2008 using a Kovacs manual corer. Samples were collected every $30 \mathrm{~cm}$ to a depth of $7.2 \mathrm{~m}$. All snow samples were later analyzed for total mercury using EPA method 1631 (detection limit $\sim 1 \mathrm{ng}^{-1}$ ).

\section{Quality assurance}

The mercury system was leak tested, flow rate verified, and zero-air tested at least daily. The Tekran model 2537a internal permeation source calibrations were performed at 26$\mathrm{h}$ intervals. All snow samples were refrigerated and handcarried back to the analysis laboratory. Water blanks, bubbler blanks, and NIST standards were analyzed in conjunction with the snow samples following EPA method 1631 for determining total mercury in the range of $0.5-100 \mathrm{ng}^{-1}$ (Titled - Mercury in water by oxidation, purge, and trap, and cold vapor atomic fluorescence spectrometry). Tekran (2005) lists the GEM detection limit of the base 2537a unit as $\sim 1 \mathrm{pg} \mathrm{m}^{-3}$, with a instrument precision of $0.06 \mathrm{ng} \mathrm{m}^{-3}$. We calculated our speciation (RGM and FPM) detection limit ( $3 \times$ field blank standard deviation) to be $0.955 \mathrm{pg} \mathrm{m}^{-3}$ (rounded to 1.0).

\section{Results}

GEM measurements generally showed variations around northern hemispheric ambient levels of 1.31 and $1.45 \mathrm{ng} \mathrm{m}^{-3}$, for 2007 and 2008, respectively (Table 1 and, Figs. 1 and 2). GEM diurnals dips were generally on the order of $0.1 \mathrm{ng} \mathrm{m}^{-3}$, and were most often accompanied by a nearly equal increase in RGM on the order of $100 \mathrm{pg} \mathrm{m}^{-3}$. RGM and FPM concentrations ranged from below detection limit (BDL; $\sim 1.0 \mathrm{pg} \mathrm{m}^{-3}$ ) to $246.8 \mathrm{pg} \mathrm{m}^{-3}$ and $151.3 \mathrm{pg} \mathrm{m}^{-3}$, respectively. Surface snow collected every other day throughout the 2007 and 2008 campaigns averaged $5.6 \mathrm{ngl}^{-1}$ for total mercury with no apparent trends. Missing FPM data late in the 2007 campaign was due to a recurring electrical short in the model 1135 particulate heater unit. Short missing GEM periods in 2008 were due to problems associated with the fouling of an in-line soda-lime trap, just upstream of the Tekran 2537a inlet. This problem 
Table 1. All mercury atmospheric speciation and total mercury in snow measurements at Summit, Greenland. Dates are 13 May-15 June 2007, and 6 June-17 July 2008. Below Detection limit (B.D.L.) denotes that values were below the detection limit $\left(<1.0 \mathrm{pg} \mathrm{m}^{-3}\right)$ of the instrument. Also shown is total mercury in surface snow collected every other day and the single core to a depth of $7.1 \mathrm{~m}$ obtained in 2008 . Coefficient of variation is the standard deviation divided by the mean.

\begin{tabular}{llllll}
\hline 2007 & Average & $\begin{array}{l}\text { Standard } \\
\text { deviation }\end{array}$ & Minimum & Maximum & $\begin{array}{l}\text { Coeff. of } \\
\text { variation }\end{array}$ \\
\hline GEM $\left(\mathrm{ng} \mathrm{m}^{-3}\right)$ & 1.31 & 0.21 & 1.04 & 3.49 & 0.16 \\
RGM $\left(\mathrm{pg} \mathrm{m}^{-3}\right)$ & 41.6 & 42.9 & B.D.L. & 246.8 & 1.03 \\
FPM $\left(\mathrm{pg} \mathrm{m}^{-3}\right)$ & 37.2 & 31.9 & B.D.L. & 151.3 & 0.86 \\
\hline 2008 & & & & & \\
\hline GEM $\left(\mathrm{ng} \mathrm{m}^{-3}\right)$ & 1.45 & 0.11 & 1.12 & 1.88 & 0.08 \\
RGM $\left(\mathrm{pg} \mathrm{m}^{-3}\right)$ & 13.2 & 19.0 & B.D.L. & 122.6 & 1.44 \\
FPM $\left(\mathrm{pg} \mathrm{m}^{-3}\right)$ & 6.7 & 8.7 & B.D.L. & 61.5 & 1.30 \\
\hline All Surface Snow & $5.6 \mathrm{ng} \mathrm{l}^{-1}$ & $4.3 \mathrm{ngl}^{-1}$ & $\left.1.3 \mathrm{ng} \mathrm{l}\right|^{-1}$ & $22.9 \mathrm{ng} \mathrm{l}^{-1}$ & 0.77 \\
Snow core 1 to $7.1 \mathrm{~m}^{-1}$ at every $~ 30 \mathrm{~cm}^{-1}$ & $3.0 \mathrm{ngl}^{-1}$ & $0.3 \mathrm{ngl}^{-1}$ & $2.6 \mathrm{ngl}^{-1}$ & $4.1 \mathrm{ng} \mathrm{l}^{-1}$ & 0.10 \\
\hline
\end{tabular}

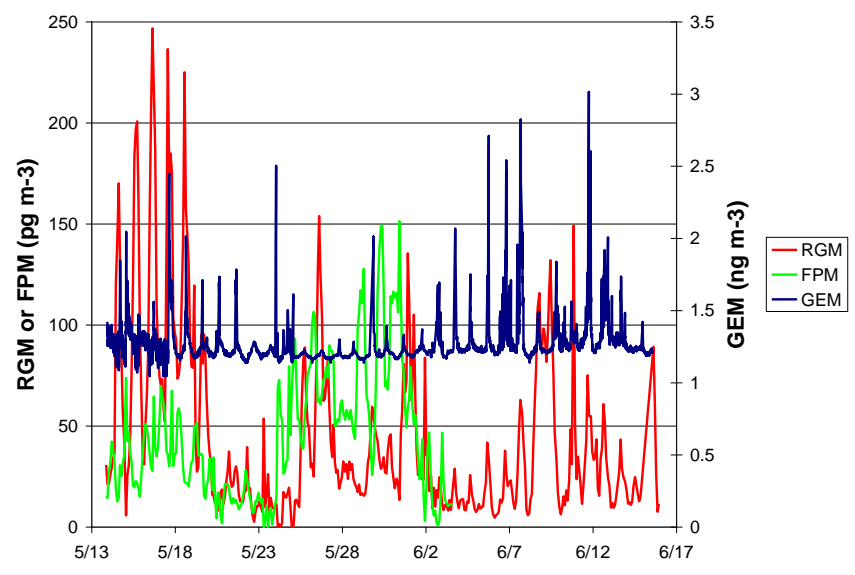

Fig. 1. All atmospheric mercury speciation data from the 2007 campaign. The measured species are reactive gaseous mercury (RGM), fine particulate mercury (FPM), and gaseous elemental mercury (GEM).

was eventually traced back to a specific batch of soda-lime. RGM and FPM are reported for this period because, unlike GEM, these measurements are based on a "difference method", where a near constant source of $\mathrm{Hg}$ contamination can be easily subtracted from the observations. The average diurnal patterns for the measured mercury species for all the 2007 campaign are shown in Fig. 3.

Overall the levels of $\mathrm{BrO}$ were lower and less diurnally consistent in 2008 compared to 2007, even when comparing the same June overlap period (Stutz et al., 2011; Liao et al., 2011; Dibb et al., 2010). Total mercury in surface snow was slightly less in 2008 than in 2007 during the overlap period, and GEM showed significantly less variation in 2008.

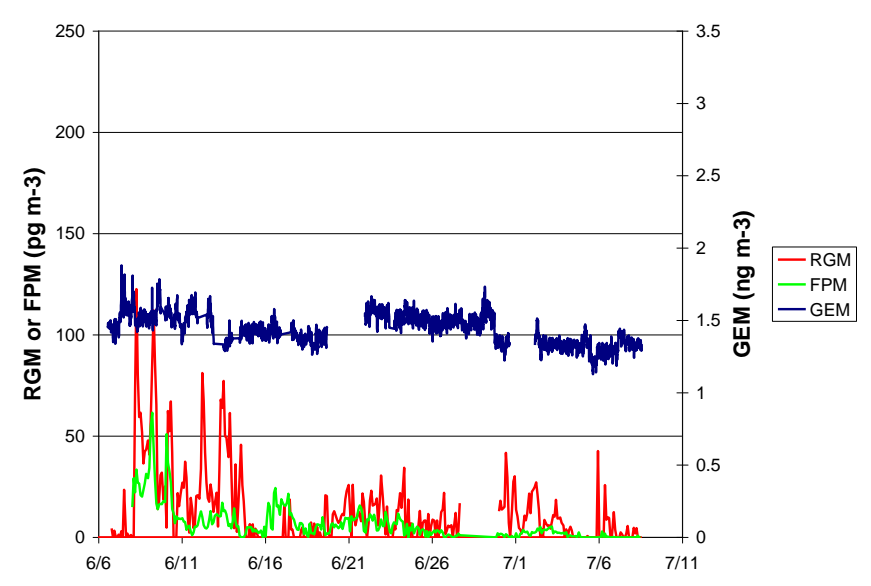

Fig. 2. All atmospheric mercury speciation data from the 2008 campaign.

\subsection{Results from selected periods}

When comparing concentrations of GEM, RGM, FPM, and $\mathrm{BrO}$, with lifetimes of months, hours, hours to days, and seconds, respectively, it is often difficult to find representative time periods. Here we have selected two multiday periods free from marine and upper tropospheric influences. Our selected periods are times of relatively stationary meteorology, or at least multi-day time periods with a similar diurnal meteorological pattern.

Utilizing FLEXPART (Lagrangian particle dispersion model) Stutz et al. (2011) identified our first period, 1419 May 2007, as the sole case during the 2007 campaign when the air mass recirculated over the Greenland ice sheet for days prior to our measurements. The air mass had remained fairly close to the surface of the Greenland ice sheet 


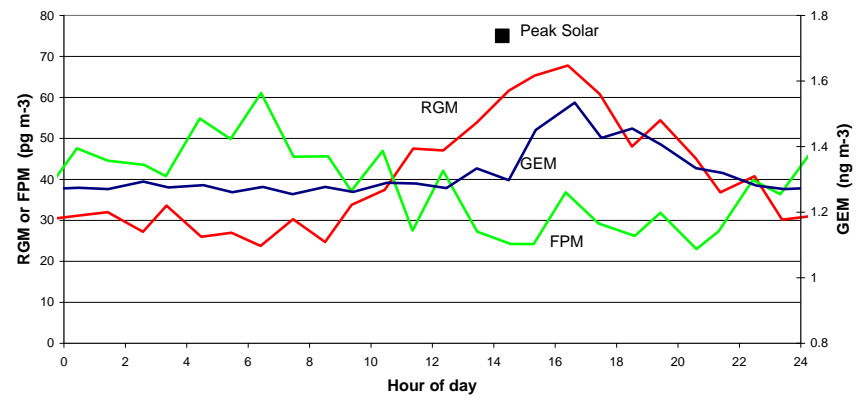

Fig. 3. Hourly diurnal averages for all 2007 campaign measurements.

for $>2$ days prior to reaching the station. This is important to eliminate the influences of marine air and upper tropospheric air.

Likewise our second period, 7-13 June 2008, was the longest period during the 2008 campaign where, again, FLEXPART showed that the air mass had remained fairly close to the surface of the Greenland ice sheet for $>2$ days prior to reaching the station. In addition this was the sole period selected by Thomas et al. (2011b) for their focused modeling analysis, due mainly to the lack of marine or upper tropospheric influences, and consistent meteorological conditions.

The two periods presented in detail in the paper were also the only multiday ( $>48 \mathrm{~h}$ ) periods of consistent (lowest variation) and low wind speeds. Large variability in wind speeds would have the confounding effect of rapidly changing the depth and volume of the mixing layer, entraining air from above when wind speeds increase, and leaving residual layers aloft when the wind speeds drop. The winds are plotted in Liao et al. (2011). These selected data periods best illustrate the solar and temperature controls without the confounding influences of upper tropospheric air, rapidly varying winds and mixing layer depths, or recent marine influences.

The first period of interest, 14-19 May 2007, is shown in Fig. 4, with the average diurnal patterns shown in Fig. 5. Here the sun dips to near-zero elevation at night, and temperatures were consistently $<-15^{\circ} \mathrm{C}$. Winds were light $(1-$ $6 \mathrm{~m} \mathrm{~s}^{-1}$ ), precipitation was negligible, blowing snow was absent, and skies were generally clear.

For this period, 14-19 May 2007, we see the obvious signs of daily GEM oxidation to RGM. Mercury showed distinct diurnal changes in speciation that appear consistent with midday Br photochemistry. GEM diurnally dipped at midday, while RGM was increasing. RGM then decreased after midday with deposition to the snow surface. GEM spiked just after peak solar, consistent with photoreduction and surface emissions of the recently deposited RGM. Also FPM was elevated at night, out of phase with the RGM, possibly due to colder temperatures favoring RGM absorption onto particles. Ozone also showed a midday diurnal dip, dropping

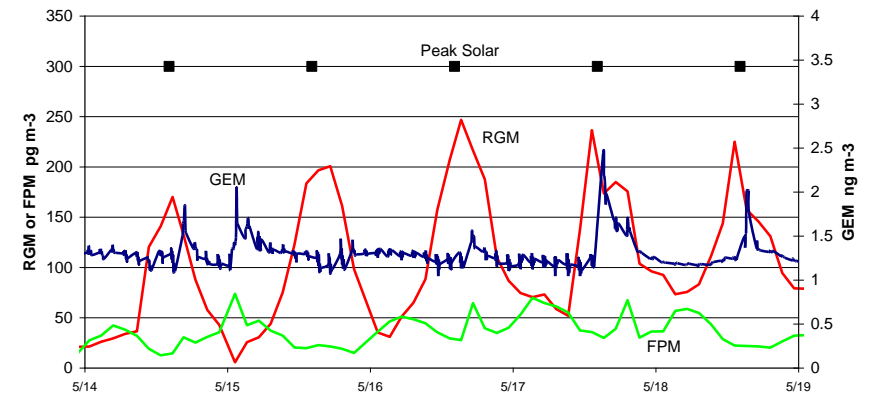

Fig. 4. Reactive gaseous mercury (RGM), fine particulate mercury (FPM), gaseous elemental mercury (GEM), and times of peak solar elevation at Summit, Greenland, 14-19 May 2007.

Hour averages May 14 - 192007
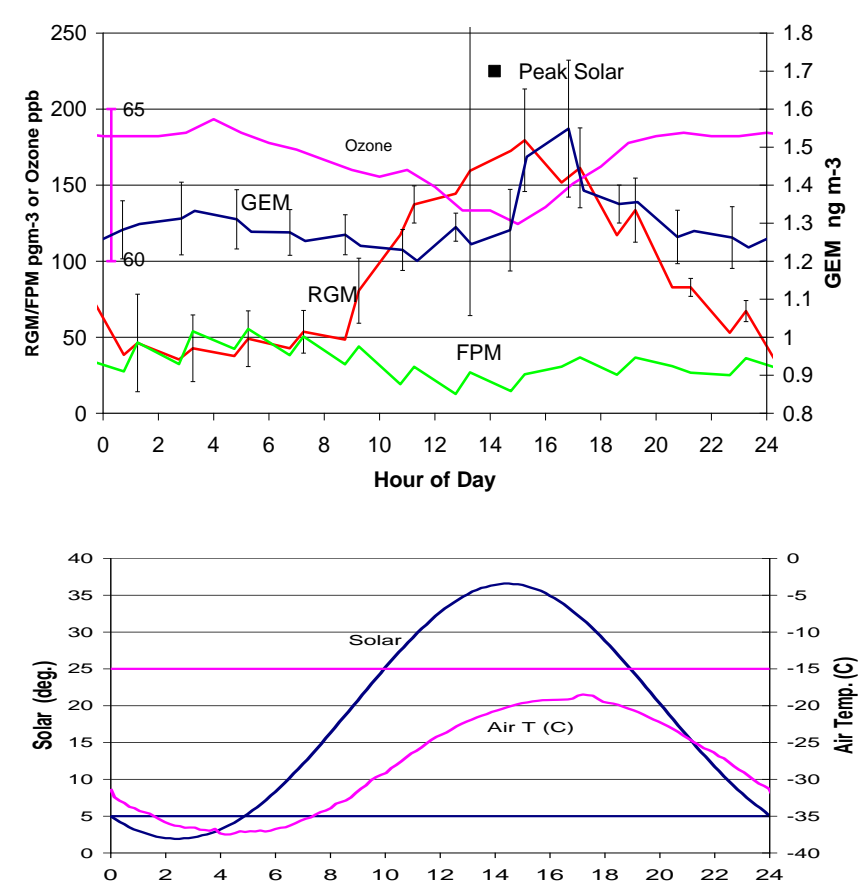

Fig. 5. Diurnal hourly averages of RGM, GEM, FPM and ozone at Summit, 14-19 May 2007. Daily RGM peaks with maximum solar elevation. RGM and GEM are shown with standard deviation bars. Solar elevation and air temperature are shown with our modeled thresholds of 5 degree solar elevation and $-15^{\circ} \mathrm{C}$.

$\sim 3 \mathrm{ppb}$, consistent with $\mathrm{Br}$ chemistry, and anti-correlated with RGM. Daily GEM conversion to RGM appears to begin when the solar elevation rises above 5 degree, and ends when the solar elevation angle drops below 5 degree.

The average diurnal patterns for the second period of interest, 7-13 June 2008, are shown in Fig. 6. Winds varied between $2-7 \mathrm{~m} \mathrm{~s}^{-1}$, again precipitation was negligible, blowing snow was absent, and skies were generally clear. The sun was significantly above the horizon $24 \mathrm{~h}$ a day, and temperatures varied from -27 to $-7^{\circ} \mathrm{C}$. Here we see a substantially 

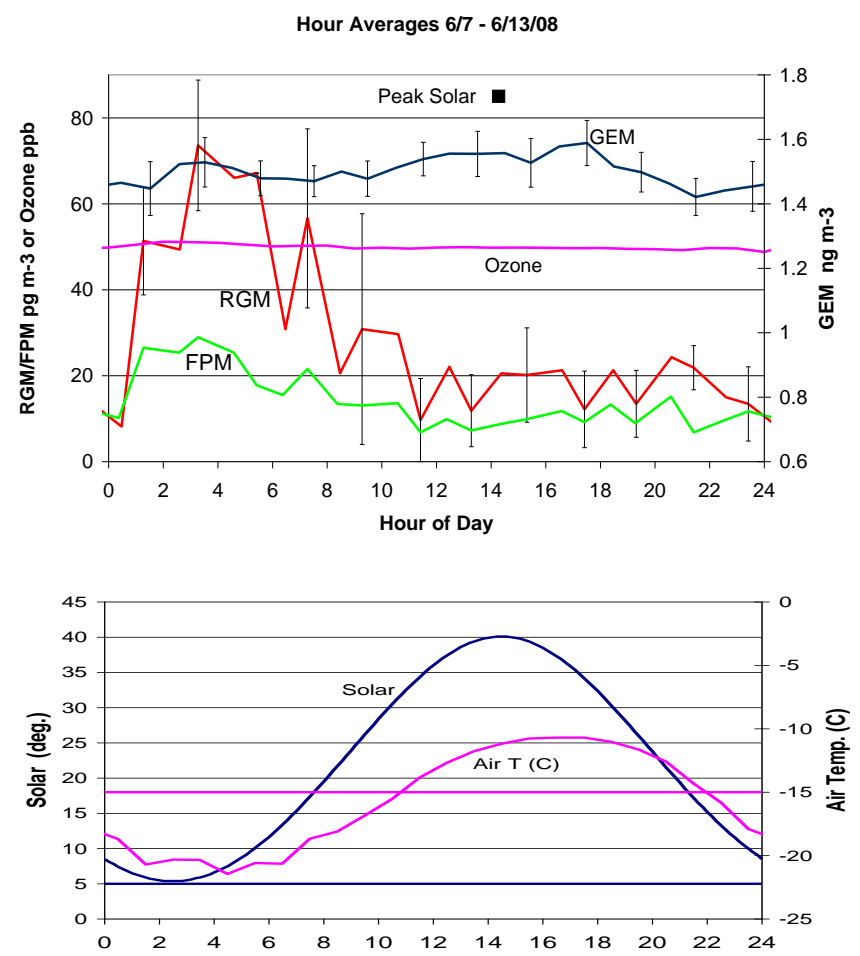

Fig. 6. Diurnal hourly averages of RGM, GEM, FPM and ozone at Summit, 7-13 June 2008. Daily RGM peaks with colder "nighttime" temperatures. RGM and GEM are shown with standard deviation bars. Solar elevation and air temperature are shown with our modeled thresholds of 5 degree solar elevation and $-15^{\circ} \mathrm{C}$.

different diurnal pattern from our first period shown in Fig. 5. GEM does not dip noticeably, but the afternoon photoreduction and surface emissions are still present, as demonstrated by the afternoon GEM enhancements. RGM and FPM are both peaking at "night" during colder $\left(<-15^{\circ} \mathrm{C}\right)$ temperatures. Daily GEM conversion to RGM appears to begin when air temperatures drop below $-15^{\circ} \mathrm{C}$, and ends when air temperatures rise above $-15^{\circ} \mathrm{C}$. Ozone shows no discernable diurnal cycle.

The late springtime boundary layer at Summit is characterized by highly stable conditions with strong surface temperature inversions. These stable conditions change to neutral or slightly unstable conditions resulting in enhanced mixing depths of $\sim 70-250 \mathrm{~m}$ during an $\sim 8 \mathrm{~h}$ "daytime" period centered around local solar noon (Helmig et al., 2002). Chemical species thought to be emitted from the snowpack, such as NO and often BrO, showed diurnal profiles with minima at solar noon due to a larger mixing volume (Thomas et al., 2011a; Dibb et al., 2010). While a portion of the RGM and FPM diurnal dips, during 7-13 June 2008 period (Fig. 6), around solar noon can likely be attributed to dilution in the larger mixing volume, boundary layer dilution alone cannot account for most of the mercury observations (i.e. GEM, RGM and FPM in period 1, and GEM in period 2). If, on the other hand,
RGM from aloft is potentially mixed downwards via entrainment in an expanding boundary layer, then the midday minima of RGM and FPM in period 2 cannot be explained. We conclude that boundary layer dynamics alone do not explain our mercury observations.

\section{Bromine/mercury chemistry}

If Greenland near surface atmospheric mercury chemistry is similar to other polar locations (Steffen et al., 2008), then under sunlit conditions bromine gas dissociates, catalyzes the destruction of ozone, and oxidizes gaseous elemental mercury $\left(\mathrm{GEM}\right.$ or $\mathrm{Hg}^{\mathrm{O}}$ ) to reactive gaseous mercury (RGM) via:

$$
\begin{aligned}
& \mathrm{Br}_{2}+h \nu \rightarrow 2 \mathrm{BrJ}\left(\mathrm{Br}_{2}\right) \\
& \mathrm{Br}+\mathrm{O}_{3} \rightarrow \mathrm{BrO}+\mathrm{O}_{2} \\
& \mathrm{BrO}+\mathrm{BrO} \rightarrow \mathrm{Br}_{2}+\mathrm{O}_{2}
\end{aligned}
$$

or

$\mathrm{Hg}^{\mathrm{o}}+\mathrm{Br} \leftrightarrow \mathrm{HgBr}$

(radical precursor to RGM, favored by cold temperatures)

The mercury bromide radical $\mathrm{Hg}(\mathrm{I})$ formed in the above mechanism thermally dissociates or may react further with e.g. $\mathrm{Br}, \mathrm{OH}$, or $\mathrm{Cl}$, leading to reactive gaseous mercury as $\mathrm{Hg}$ (II) (Goodsite et al., 2004; Holmes et al., 2006). Therefore the fates of $\mathrm{HgBr}$ include:

$$
\begin{aligned}
& \mathrm{HgBr} \leftrightarrow \mathrm{Hg}+\mathrm{Br} \mathrm{K} 1 \text { (dissociation) } \\
& \mathrm{HgBr}+\mathrm{Br} \rightarrow \mathrm{HgBr}_{2} \quad \mathrm{~K} 2 \\
& \mathrm{HgBr}+\mathrm{OH} \rightarrow \mathrm{HgBrOH} \mathrm{K} 3 \\
& \mathrm{HgBr}+\mathrm{Cl} \rightarrow \mathrm{HgBrCl} \mathrm{K} 4
\end{aligned}
$$

RGM Production $=[\mathrm{HgBr}](\mathrm{K} 2[\mathrm{Br}]+\mathrm{K} 3[\mathrm{OH}]$

$$
+\mathrm{K} 4[\mathrm{Cl}])-\mathrm{K} 1[\mathrm{HgBr}]
$$

The newly formed RGM then deposits rapidly to the snow pack with a high deposition velocity $\left(\sim 1 \mathrm{~cm} \mathrm{~s}^{-1}\right.$; Skov et al., 2006), or becomes bound to airborne particles forming FPM. The global control on this mechanism is thought to be thermal dissociation of $\mathrm{HgBr}$ prior to forming the stable RGM (HgBrX; Goodsite et al., 2004; Holmes et al., 2006). The lifetime against thermal dissociation of $\mathrm{HgBr}$ is thought to double with every 6 degree Celsius drop in temperature (Holmes et al., 2006). Holmes et al. (2006) also concluded that broad uncertainties in the kinetic rates, especially for reactions involving $\mathrm{HgBr}$ as a reactant, need to be resolved in order to validate this as a functioning mechanism. Here we will assume this is a valid mechanism, and seek to determine the sunlight and temperature (thermal dissociation) controls. 
$5 / 14-5 / 19 / 2007$

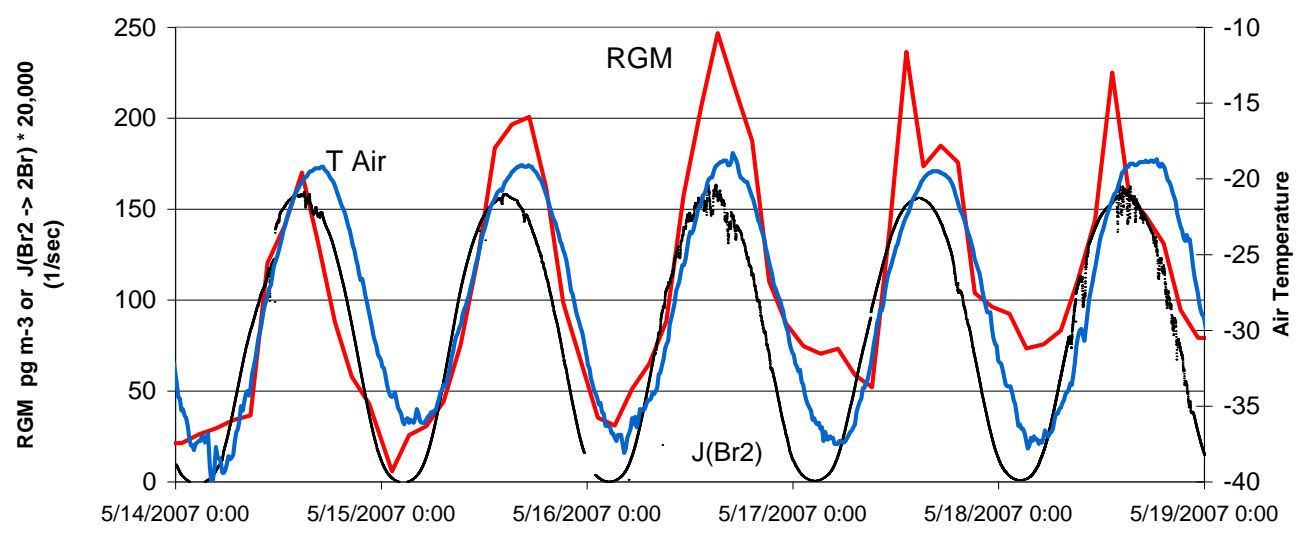

Fig. 7. Reactive gaseous mercury ( $\mathrm{RGM}), \mathrm{J}\left(\mathrm{Br}_{2}+h v=>2 \mathrm{Br}\right)$, and air temperature at Summit, Greenland, 14-19 May 2007. Correlation coefficients for RGM-J $\left(\mathrm{Br}_{2}\right)$ and RGM-Temperature are $r=0.85$ and $r=0.84$, respectively.

Atomic bromine is one of just a few species known to effectively oxidize GEM (Ariya et al., 2002; Donohue et al., 2006). Other potential species include ozone, $\mathrm{OH}$, and $\mathrm{BrO}$ which have been included in polar $\mathrm{Hg}$ modeling (Ariya et al., 2004; Dastoor et al., 2008; Seigneur and Lohman, 2008). These modeling results generally suggest that $\mathrm{Br}$ is the predominant oxidation pathway, and other investigations also indicate that oxidation via ozone and $\mathrm{OH}$ is likely too slow to be major atmospheric pathways (Calvert and Lindberg, 2005; Hynes et al., 2008; Holmes et al., 2010). The modeling work of Liao et al. (2011) and Thomas et al. (2011b) also suggest that our observations of near-surface mercury species at Summit is most consistent with bromine chemistry, and with the sunlit snow surface as the bromine source.

We can estimate the required $[\mathrm{Br}]$ to produce our average observed [RGM] and [GEM]. There is a clear diurnal cycle of RGM. Daily minima of RGM suggest that deposition to the snow is a strong sink, and imply an RGM lifetime against deposition at Summit during our campaign in the $3-10 \mathrm{~h}$ range. We will assume a $k_{\mathrm{d}}$ of $1 /(7 \mathrm{~h})$. Likewise, the observed daily increase of RGM occurs over $\sim 6 \mathrm{~h}$ period. This time rate of change of $[\mathrm{RGM}]$ is therefore equal to production minus deposition, or $k[\mathrm{Br}][\mathrm{GEM}]-k_{\mathrm{d}}[\mathrm{RGM}]$. The necessary [Br] can then be estimated by:

$$
[\mathrm{Br}]=\frac{[\mathrm{RGM}]}{[\mathrm{GEM}] \cdot k_{\mathrm{Br}+\mathrm{GEM}} \cdot(7 \mathrm{~h})}+\frac{[\mathrm{RGM}]}{[\mathrm{GEM}] \cdot k_{\mathrm{Br}+\mathrm{GEM}} \cdot(6 \mathrm{~h})}
$$

It should be noted that $k_{\mathrm{Br}+\mathrm{GEM}}$ is not well established, with determinations reported by Ariya et al. (2002) and Donohoue et al. (2006) of $(3.2 \pm 0.3) \times 10^{-12}$ and $(3.6 \pm 50 \%) \times 10^{-13} \mathrm{~cm}^{3}$ molecule $\mathrm{s}^{-1} \mathrm{~s}^{-1}$, respectively. As these rates differ by an order of magnitude, the estimated $[\mathrm{Br}]$ is highly uncertain. Using $[\mathrm{RGM}]=100 \mathrm{pg} \mathrm{m}^{-3}$ and $[\mathrm{GEM}]=1500 \mathrm{pg} \mathrm{m}^{-3}$, [Br] equates to $1.3 \times 10^{6}$ and $1.1 \times 10^{7}$ molecule $\mathrm{cm}^{-3}(\sim 0.06$ and $0.6 \mathrm{pptv})$ based on the rates of Ariya et al. (2002) and Donohoue et al. (2006), respectively. These levels are within modeled estimates of Thomas et al. (2011b).

In the past it has been difficult to isolate the influences of $\mathrm{J}\left(\mathrm{Br}_{2}\right)$, and the thermal decomposition lifetime of $\mathrm{HgBr}$. At coastal locations $\mathrm{Br}_{2}$ concentrations vary with marine versus continental air, and rapidly changing sea ice conditions. Non-homogeneous upwind conditions may transport RGM and/or $\mathrm{Br}$ into the measurement location. Periods of varying winds, which affect boundary layer depths and mixing, confound efforts to isolate these variables. Air from the upper troposphere may mix down oxidized mercury from aloft (Talbot et al., 2008; Swartzendruber et al., 2008). For our two distinct periods at Summit, Greenland the above confounding effects are absent or minimal.

Figures 7 and 8 show RGM from our selected periods, air temperature and $\mathrm{J}\left(\mathrm{Br}_{2}\right)$ for the photodissocation production of monatomic Br. During the period 14-19 May (Fig. 7), the air temperature was consistently below $-15^{\circ} \mathrm{C}$ and $\mathrm{RGM}$ was strongly correlated to $\mathrm{J}\left(\mathrm{Br}_{2}\right)$ and temperature $(r=0.85$ and 0.84 , respectively). RGM peaks were well defined at maximum solar elevations and RGM was minimal at "night".

During the period 7-13 June (Fig. 8), the air temperature varied from -27 to $-7^{\circ} \mathrm{C}$, and thermal dissociation of $\mathrm{HgBr}$ dominated over the formation of $\mathrm{HgBrX}$ during the higher midday air temperatures. $\mathrm{J}\left(\mathrm{Br}_{2}\right)$ was well above zero over the $24 \mathrm{~h}$ per day of sunlight. RGM enhancements were decoupled from solar $\mathrm{J}\left(\mathrm{Br}_{2}\right)(r=-0.39)$, and were significantly anti-correlated $(r=-0.75)$ to air temperatures. In addition to the longer lifetime of $\mathrm{HgBr}$ against thermal decomposition (further oxidizing to RGM), low solar elevation and colder temperatures generally favor $\mathrm{Br}$ and $\mathrm{BrO}$, due to decreases in the $\mathrm{HO}_{\mathrm{x}}$ sinks (von Glasow et al., 2002; Hedgecock and Pirrone, 2004; Liao et al., 2011) and increased Br production from aerosols, via the solubility of HOBr (Vogt et al., 1999). 


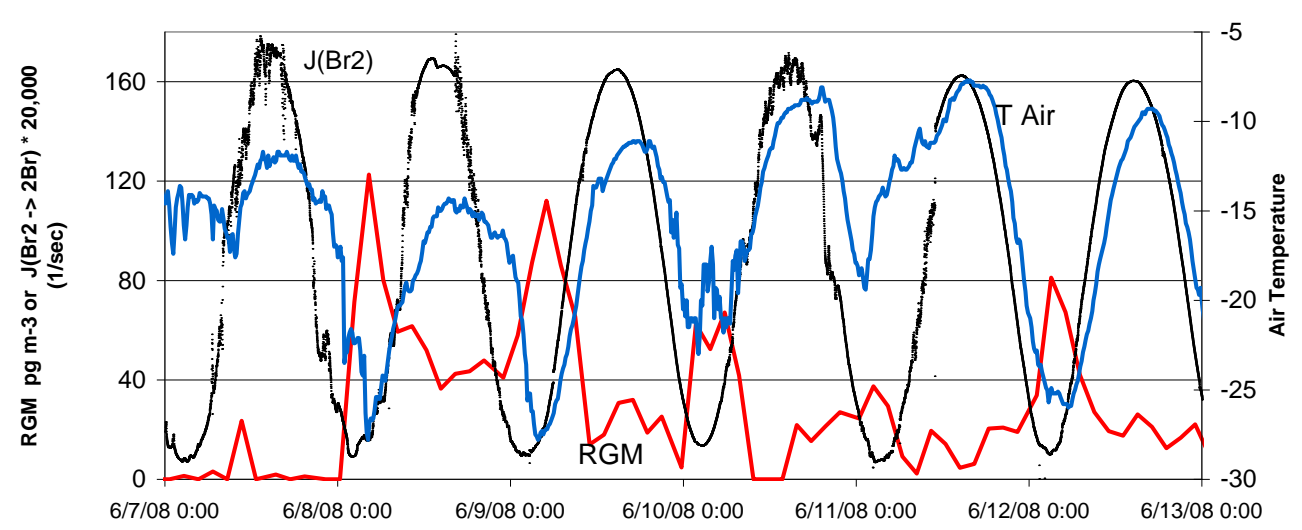

Fig. 8. Reactive gaseous mercury ( $\mathrm{RGM}), \mathrm{J}\left(\mathrm{Br}_{2}+h v=>2 \mathrm{Br}\right)$, and air temperature at Summit, Greenland, 7-13 June 2008. Correlation coefficients for RGM-J $\left(\mathrm{Br}_{2}\right)$ and RGM-Temperature are $r=-0.39$ and $r=-0.75$, respectively.

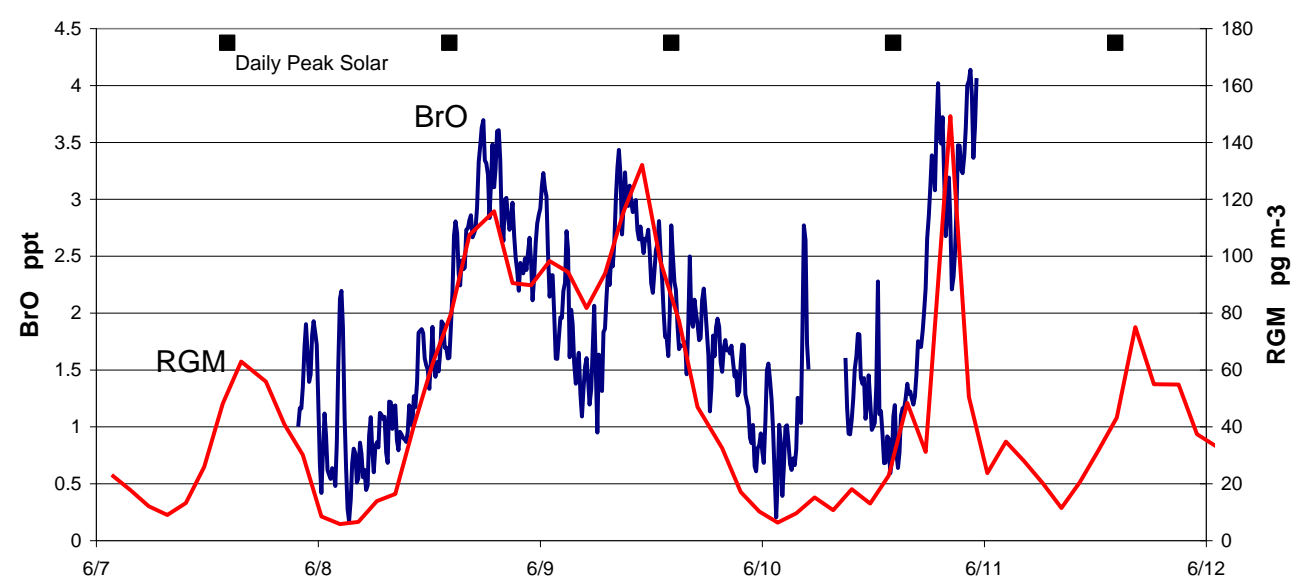

Fig. 9. RGM and BrO from CIMS, $2007(r=0.76)$.

However, as shown in Fig. 6, there is no discernable diurnal cycle in ozone concentration that would indicate diurnal enhancements of $\mathrm{Br}$ or $\mathrm{BrO}$.

Direct [BrO] measurements in 2007 and 2008 were hampered by instrumentation problems, and morning fog for the DOAS system (Stutz et al., 2011; Liao et al., 2011). This is the reason our modeling results presented here are based on solar angle and $\mathrm{J}(\mathrm{Br} 2)$, not direct [BrO]. An exception is the period 7-11 June 2007 when we have our strongest confidence in the $\mathrm{BrO}$ data. Figure 9 shows this period of $\mathrm{BrO}$, from continuous CIMS measurements for 7-11 June 2007, and RGM. From the 2007 campaign the [BrO] measurements from CIMS were not reported before 27 May due to technical problems. After 27 May the BrO data showed significant noise until the instrumentation was restarted on 7 June (Liao et al., 2011). Figure 9 shows [BrO] from 7 June to the end point of the 2007 [BrO] measurements on 11 June. RGM and $\mathrm{BrO}$, as expected, are significantly correlated ( $r=0.76)$ over this period.

\section{Modeling the sun elevation and air temperature controls on GEM conversion to RGM}

Based on these observations we conclude that by assuming consistent concentrations of $\mathrm{X}(\mathrm{Br}, \mathrm{Cl}, \mathrm{OH})$ in the reactions $\mathrm{HgBr}+\mathrm{X}=>\mathrm{HgBrX}$, we can define the solar elevations and temperatures where GEM conversion to RGM should occur. We calculate that GEM oxidation to RGM ( $\mathrm{Hg}(\mathrm{II}))$ atop the Greenland ice cap requires solar elevation angles $>5$ degree and air temperatures $<-15^{\circ} \mathrm{C}$. These thresholds are shown in the bottom plots of Figs. 5 and 6 . We expect this assumption to fail at coastal locations where $\mathrm{X}$ species $(\mathrm{Br}$ and $\mathrm{Cl})$ are episodically enriched. At Point Barrow, Alaska, at a similar latitude as Summit, Greenland, we have measured significant concentrations of RGM ( $>10 \mathrm{pg} \mathrm{m}^{-3}$ ) up to a temperature of $-6^{\circ} \mathrm{C}$ (Lindberg et al., 2002).

Figure 10 shows the scatter plots of RGM and air temperature, and, RGM and solar elevation, along with our modeled thresholds of 5 degree solar elevation and $-15^{\circ} \mathrm{C}$. We 

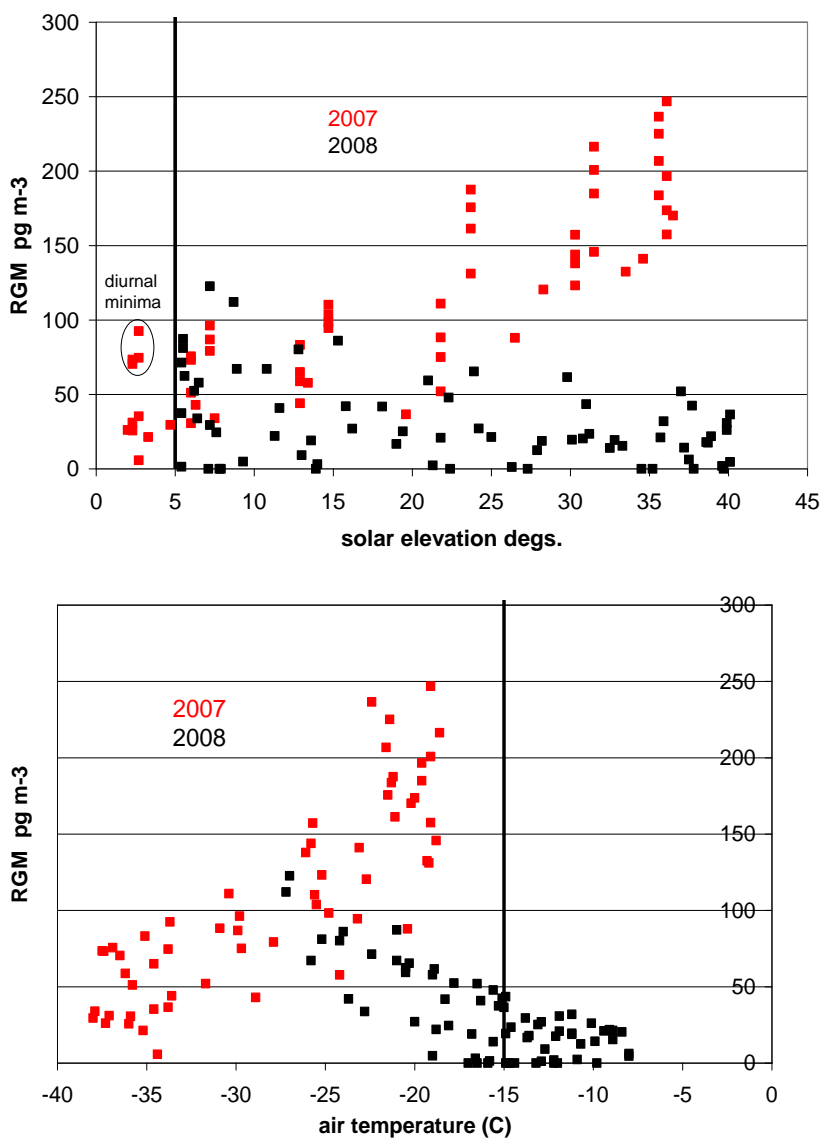

Fig. 10. RGM versus air temperature and RGM versus solar elevation angle. Solar elevation and air temperature are shown with our modeled thresholds of 5 degree solar elevation and $-15^{\circ} \mathrm{C}$.

assume $[\mathrm{RGM}]<50 \mathrm{pg} \mathrm{m}^{-3}$ to be residual concentrations, not an indication of RGM production. All measured [RGM] above $100 \mathrm{pg} \mathrm{m}^{-3}$ in 2007 and 2008 occur at times when solar elevation $>5$ degree and air temperature $<-15^{\circ} \mathrm{C}$. The few instances when RGM was between 50 and $100 \mathrm{pg} \mathrm{m}^{-3}$ when solar elevation was below 5 degree were times of "nighttime" RGM minima.

\section{Discussion and extrapolation to the vast Greenland ice sheet}

The Greenland ice sheet covers an area of $\sim 14$ million square $\mathrm{km}$ with an annual snow accumulation rate of $\sim 300 \mathrm{~kg} \mathrm{~m}^{-2}$ (Bales et al., 2001). From our snow coring measurements, total mercury averages $3.0 \mathrm{ng}^{-1}$ at depth $(>1 \mathrm{~m})$, with a standard deviation of $0.3 \mathrm{ng} \mathrm{l}^{-1}$. This is based on 20 samples collected every $30 \mathrm{~cm}$ to a depth of $7.1 \mathrm{~m}$, representing $\sim 10 \mathrm{yr}$ of accumulation. From these values we calculate that the Greenland ice sheet sequesters $\sim 13$ metric tons $\mathrm{Hg}$ per year at depth. We postulate that, while a portion of the deposited RGM is photoreduced and re-emitted, a small frac-

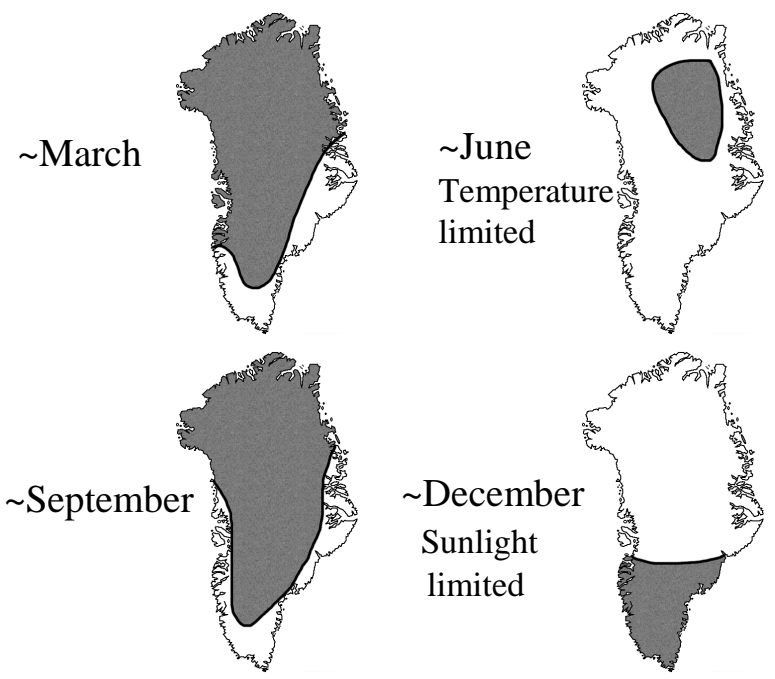

Fig. 11. Seasonal plots of the area of the Greenland ice cap where solar elevation exceeds 5 degree and where the average daily low temperature is $<-15^{\circ} \mathrm{C}$ (shaded). These shaded areas represent the locations where we would expect RGM production and deposition.

tion of deposited mercury is buried by falling or drifting snow below the sunlit zone (top $\sim 10 \mathrm{~cm}$ ), becoming sequestered long-term. We present this 13 tons per year number as a first estimate, as there are clearly problems associated with extrapolating one point to the remainder of the vast Greenland ice sheet.

Using solar elevation $>5$ degree and air temperatures $<-15^{\circ} \mathrm{C}$ as the criteria for RGM production, we generated the RGM formation maps (shaded regions) shown in Fig. 11. RGM production is predicted in the southern half of the ice cap from the beginning of January, and proceeds northward during February and covering nearly all of Greenland by March and April. In May, average temperatures rise well above $-15^{\circ} \mathrm{C}$ in southern Greenland and at the lower coastal elevations. By June, RGM production is restricted to the higher ice sheet elevations. These conditions persist through the summer months. In October, the area of RGM production begins to increase with dropping temperatures. By November, RGM production halts in the Northern half of Greenland due to lack of sunlight. In December, only the southern half of Greenland experiences RGM production.

Regional warming at high latitudes will likely reduce RGM production and deposition.

Should the Greenland ice sheet warm considerably, the periods of solar elevation $>5$ degree with temperatures below $<-15^{\circ} \mathrm{C}$ would decrease in duration. This would likely lead to lower rates of RGM formation and lower deposition rates. On the other hand, warmer temperatures could result in increased snow accumulation and increased $\mathrm{Hg}$ burial rates. 


\section{Conclusions}

Halogen (such as bromine, $\mathrm{Br}$ ) chemistry is normally associated with marine boundary layers, not remote high-altitude ice sheets. However, at Summit, Greenland, we have conclusively detected bromine and mercury chemistry in the near surface air. Likely the fate of the mercury-bromine radical $(\mathrm{HgBr})$ is further oxidation to stable $\mathrm{RGM}\left(\mathrm{HgBr}_{2}, \mathrm{HgBrOH}\right.$, $\mathrm{HgBrCl} \ldots$ ), or thermal decomposition. These fates appear to be controlled by the availability of $\mathrm{Br}, \mathrm{OH}, \mathrm{Cl}$, etc. to produce RGM, versus the lifetime of $\mathrm{HgBr}$ by thermal dissociation. At Summit, the production of RGM appears to require a sun elevation angle of $>5$ degrees, and an air temperature of $<-15^{\circ} \mathrm{C}$. We propose that the availability of $\mathrm{Br}$, controlled by photolysis $\mathrm{J}\left(\mathrm{Br}_{2}\right)$, requires a sun angle $>5$ degrees, while the formation of RGM (Hg II) from $\mathrm{HgBr}(\mathrm{Hg}$ I) requires a temperature $<-15^{\circ} \mathrm{C}$.

At Summit most of the deposited RGM is readily photoreduced and re-emitted to the air as GEM. However, a very small fraction becomes buried at depth resulting in an estimated annual sequestration of $\sim 13$ metric tons $\mathrm{Hg}$ per year for the Greenland ice sheet.

We assume here that the chemical composition of the nearsurface air over the vast Greenland ice sheet does not vary significantly from those measured at Summit, giving a temperature threshold for RGM formation of $<-15^{\circ} \mathrm{C}$. We expect this assumption to fail at coastal locations near the sea ice where $\mathrm{Br}$ is significantly more enriched.

Acknowledgements. We would like to acknowledge the Summit staff for their support. Maria Hörhold and Kristina Sorg for their assistance obtaining the snow core with the Kovacs hand corer. We thank NSF for their support and NOAA/ESRL/GMD for their archived meteorology data.

Edited by: J. Dibb

\section{References}

Ariya, P. A., Khalizov, A., and Gidas, A.: Reactions of gaseous mercury with atomic and molecular halogens: Kinetics, product studies, and atmospheric implications, J. Phys. Chem. A, 106, 7310-7320, 2002.

Ariya, P., Dastoor, A., Amyot, M., Schroeder, W., Barrie, L., Anlauf, K., Raofie, F., Ryzhkov, A., Davignon, D., Lalonde, J., and Steffen, A.: Arctic: A sink for mercury, Tellus, 56B, 397-403, 2004.

Bales, R. C., McConnell, J. R., Mosley-Thompson, E., and Csatho, B.: Accumulation over the Greenland ice sheet from historical and recent records, J. Geophys. Res. Atmos., 106(D24), 3381333826, 2001.

Banic, C., Beauchamp, S. T., Tordon, R. J., Schroeder, W. H., Steffen, A., and Anlauf, K. A.: Vertical distribution of gaseous elemental mercury in Canada, J. Geophys. Res., 108(D9), 4264, doi:10.1029/2002JD002116, 2003.

Bartels-Rausch, T., J“ori, M., and Ammann, M.: Adsorption of mercury on crystalline ice. Annual Report, Laboratory for ra- diochemistry and environmental chemistry-Paul Scherrer Institut, Villigen, Switzerland, 2002.

Berg, T., Sekkesæter, S., Steinnes, E., Valdal, A., and Wibetoe, G.: Arctic springtime depletion of mercury in the European Arctic as observed at Svalbard, Sci. Total Environ. 304, 43-51, 2003.

Boutron, C. F., Vandal, G. M., Fitzgerald, W. F., and Ferrari, C. P.: A forty-year record of mercury in central Greenland snow, Geophys. Res. Lett., 25, 3315-3318, 1998.

Brooks, S., Saiz-Lopez, A., Skov, H., Lindberg, S., Plane, J. M. C., and Goodsite, M. E.: The mass balance of mercury in the springtime polar environment, Geophys. Res. Lett., 33, L13812, doi:10.1029/2005GL025525, 2006.

Brooks, S., Arimoto, R., Lindberg, S., and Southworth, G.: Antarctic polar plateau snow surface conversion of deposited oxidized mercury to gaseous elemental mercury with fractional long-term burial, Atmos. Environ., 42, 2877-2884, 2008.

Calvert, J. and Lindberg, S.: Mechanisms of mercury removal by O-3 and $\mathrm{OH}$ in the atmosphere, Atmos Environ, 39, 3355-3367, doi:10.1016/j.atmosenv.2005.01.055, 2005.

Dastoor, A. P., Davignon, D., Theys, N., Roozendael, M. V., Steffen, A., and Ariya, P. A.: Modeling dynamic exchange of gaseous elemental mercury at polar sunrise, Environ. Sci. Technol., 42, 5183-5188, doi:10.1021/es800291w, 2008.

Dibb, J. E., Ziemba, L. D., Luxford, J., and Beckman, P.: Bromide and other ions in the snow, firn air, and atmospheric boundary layer at Summit during GSHOX, Atmos. Chem. Phys., 10, 99319942, doi:10.5194/acp-10-9931-2010, 2010.

Dommergue, A., Ferrari, C. P., Gauchard, P.-A., Boutron, C. F., Poissant, L., Pilote, M., Jitaru, P., and Adams, F.: The fate of mercury species in a sub-arctic snow-pack during snowmelt, Geophys. Res. Lett., 30, 1621, doi:10.1029/2003GL017308, 2003.

Dommergue, A., Sprovieri, F., Pirrone, N., Ebinghaus, R., Brooks, S., Courteaud, J., and Ferrari, C. P.: Overview of mercury measurements in the Antarctic troposphere, Atmos. Chem. Phys., 10, 3309-3319, doi:10.5194/acp-10-3309-2010, 2010.

Donohoue, D. L., Bauer, D., Cossairt, B., and Hynes, A. J.: Temperature and pressure dependent rate coefficients for the reaction of $\mathrm{Hg}$ with $\mathrm{Br}$ and the reaction of $\mathrm{Br}$ with $\mathrm{Br}$ : A pulsed laser photolysis-pulsed laser induced fluorescence study, J. Phys. Chem. A, 110(21), 6623-6632, 2006.

Ebinghaus, R., Kock, H. H., Temme, C., Einax, J. W., Lowe, A. G., Richter, A., Burrows, J. P., and Schroeder, W. H.: Antarctic springtime depletion of atmospheric mercury, Environ. Sci. Technol., 36, 1238-1244, 2002.

Faïn, X., Ferrari, C. P., Dommergue, A., Albert, M., Battle, M., Arnaud, L., Barnola, J.-M., Cairns, W., Barbante, C., and Boutron, C.: Mercury in the snow and firn at Summit Station, Central Greenland, and implications for the study of past atmospheric mercury levels, Atmos. Chem. Phys., 8, 3441-3457, doi:10.5194/acp-8-3441-2008, 2008.

Ferrari, C. P., Dommergue, A., and Boutron, C. F.: Profiles of mercury in the snow pack at Station Nord, Greenland shortly after polar sunrise, Geophys. Res. Lett., 31, L03401, doi:10.1029/2003GL018961, 2004.

Fitzgerald, W. F. and Gill, G. A.: Sub-nanogram determination of mercury by a 2-stage gold amalgamation and gas-phase detection applied to atmospheric analysis, Anal. Chem., 51, 1714-1720, 1979. 
Goodsite, M. E., Plane, J. M. C., and Skov, H.: A theoretical study of the oxidation of $\mathrm{Hg}-0$ to $\mathrm{HgBr} 2$ in the troposphere, Environ. Sci. Technol., 38(6), 1772-1776, 2004.

Hedgecock, I. M. and Pirrone, N.: Chasing quicksilver: Modeling the atmospheric lifetime of $\mathrm{Hg}-(\mathrm{g})(0)$ in the marine boundary layer at various latitudes, Environ. Sci. Technol., 38 (1), 69-76, 2004.

Helmig, D., Boulter, J., David, D., Birks, J. W., Cullen, N. J., Steffen, K., Johnson, B. J., and Oltmans, S. J.: Ozone and meteorological boundary-layer conditions at Summit, Greenland, during 3-21 June 2000, Atmos. Environ., 36, 2595-2608, 2002.

Holmes, C. D., Jacob, D. J., and Yang, X.: Global lifetime of elemental mercury against oxidation by atomic bromine in the free troposphere, Geophys. Res. Lett., 33(20), L20808, doi:10.1029/2006GL027176, 2006.

Holmes, C. D., Jacob, D. J., Corbitt, E. S., Mao, J., Yang, X., Talbot, R., and Slemr, F.: Global atmospheric model for mercury including oxidation by bromine atoms, Atmos. Chem. Phys., 10, 12037-12057, doi:10.5194/acp-10-12037-2010, 2010.

Hynes, A., Donohoue, D., Goodsite, M., Hedgecock, I., Pirrone, N., and Mason, R.: Our current understanding of major chemical and physical processes affecting mercury dynamics in the atmosphere and at air-water/terrestrial interfaces, in: Mercury Fate and Transport in the Global Atmosphere, United Nations Environment Programme, 2008.

King, M. D. and Simpson, W. R.: Extinction of UV radiation in Arctic snow at Alert, Canada (82_N), J. Geophys. Res., 106, 12499_ 12507, 2001.

Lalonde, J. D., Poulain, A. J., and Amyot, M.: The role of mercury redox reactions in snow on snow-to-air mercury transfer, Environ. Sci. Technol., 36, 174-178, 2002.

Lalonde, J. D., Amyot, M., Doyon, M. R., and Auclair, J. C.: Photoinduced $\mathrm{Hg}$ (II) reduction in snow from the remote and temperate Experimental Lakes Area (Ontario, Canada), J. Geophys. Res.Atmos., 108(D6), 4200, doi:10.1029/2001JD001534, 2003.

Landis, M., Stevens, R. K., Schaedlich, F., and Prestbo, E. M.: Development and characterization of an annular denuder methodology for the measurement of divalent inorganic reactive gaseous mercury in ambient air, Environ. Sci. Technol., 36, 3000-3009, 2002.

Lindberg, S. E., Brooks, S. B., Lin, C. J., Scott, K. J., Landis, M. S., Stevens, R. K., Goodsite, M., and Richter, A.: Dynamic oxidation of gaseous mercury in the arctic troposphere at polar sunrise, Environ. Sci. Technol., 36, 1245-1256, 2002.

Lindberg, S., Bullock, R., Ebinghaus, R., Engstrom, D. R., Feng, X., Fitzgerald, W. F., Pirrone, N., Prestbo, E., and Seigneur, C.: A synthesis of progress and uncertainties in attributing the sources of mercury in deposition, Ambio, 36(1), 19-32, 2007.

Liao, J., Huey, L. G., Tanner, D. J., Brooks, S., Dibb, J. E., Stutz, J., Thomas, J. L., Lefer, B., Haman, C., and Gorham, K.: Observations of hydroxyl and peroxy radicals and the impact of BrO at Summit, Greenland in 2007 and 2008, Atmos. Chem. Phys. Discuss., 11, 12725-12762, doi:10.5194/acpd-11-127252011, 2011.

Lu, J. Y., Schroeder, W. H., Berg, T., Munthe, J., Schneeberger, D., and Schaedlich, F.: A device for sampling and determination of total particulate mercury in ambient air, Anal. Chem., 70, 24032408, 1998.

Lu, J. Y., Schroeder, W. H., Barrie, L. A., Steffen, A., Welch, H.
E., Martin, K., Lockhart, L., Hunt, R. V., Boila, G., and Richter, A.: Magnification of atmospheric mercury deposition to polar regions in springtime: the link to tropospheric ozone depletion chemistry, Geophys. Res. Lett., 28, 3219-3222, 2001.

Mann, J. L., Long, S. E., Shuman, C. A., and Kelly, W. R.: Determination of Mercury content in a shallow firn core from Greenland by isotope dilution inductively coupled plasma mass spectrometry, Water Air Soil Poll., 163, 19-32, 2005.

Mao, H., Talbot, R., Sive, B., Kim, S. Y., Blake, D. R., and Weinheimer, A. J.: Arctic mercury depletion and its quantitative link with halogens, J. Atmos. Chem., 65, 145-170, 2010.

Murphy, D. M., Thomson, D. S., and Mahoney, M. J.: In situ measurements of organics, meteoric material, mercury, and other elements in aerosols at 5 to 19 kilometers, Science, 282, 1664-1669, 1998.

Schroeder, W. H., Anlauf, K. G., Barrie, L. A., Lu, J. Y., Steffen, A., Schneeberger, D. R., and Berg, T.: Arctic springtime depletion of mercury, Nature, 394, 331-332, 1998.

Skov, H., Christensen, J. H., Goodsite, M. E., Heidam, N. Z., Jensen, B., Wahlin, P., and Geernaert, G.: Fate of elemental mercury in the Arctic during atmospheric mercury depletion episodes and the load of atmospheric mercury to the Arctic, Environ. Sci. Technol., 38, 2373-2382, 2004.

Skov, H., Brooks, S. B., Goodsite, M. E., Lindberg, S. E., Meyers, T. P., Landis, M., Larsen, M. R. B., Jensen, B., McConville, G., and Christensen, J.: Fluxes of reactive gaseous mercury measured with a newly developed method using relaxed eddy accumulation, Atmos. Environ., 40, 5452-5463, 2006.

Seigneur, C. and Lohman, K.: Effect of bromine chemistry on the atmospheric mercury cycle, J. Geophys. Res., 113(D23), 309, doi:10.1029/2008JD010262, 2008.

Sjostedt, S. J., Huey, L. G., Tanner, D. J., Pieschl, J., Chen, G., Dibb, J. E., Lefer, B., Hutterli, M. A., Beyersdorf, A. J., Blake, D. R., Sueper, D., Ryerson, T., Burkhardt, J., and Stohl, A.: Observations of hydroxyl and the sum of peroxy radicals at Summit, Greenland during summer 2003, Atmos. Environ., 41, 51225137, doi:10.1016/j.atmosenv.2006.06.065, 2007.

Slemr, F., Brunke, E. G., Ebinghaus, R., Temme, C., Munthe, J., Wangberg, I., Schroeder, W., Steffen, A., and Berg, T.: Worldwide trend of atmospheric mercury since 1977, Geophys. Res. Lett., 30(10), 1516, doi:10.1029/2003GL016954, 2003.

Steffen, A., Schroeder, W. H., MacDonald, R., Poissant, L., and Konoplev, A.: Mercury in the arctic atmosphere: an analysis of eight years of measurements of GEM at Alert (Canada) and a comparison with observations at Amderma (Russia) and Kuujjuarapik (Canada), STOTEN, 342, 185-198, 2005.

Steffen, A., Douglas, T., Amyot, M., Ariya, P., Aspmo, K., Berg, T., Bottenheim, J., Brooks, S., Cobbett, F., Dastoor, A., Dommergue, A., Ebinghaus, R., Ferrari, C., Gardfeldt, K., Goodsite, M. E., Lean, D., Poulain, A. J., Scherz, C., Skov, H., Sommar, J., and Temme, C.: A synthesis of atmospheric mercury depletion event chemistry in the atmosphere and snow, Atmos. Chem. Phys., 8, 1445-1482, doi:10.5194/acp-8-1445-2008, 2008.

Stutz, J., Thomas, J. L., Hurlock, S. C., Schneider, M., von Glasow, R., Piot, M., Gorham, K., Burkhart, J. F., Ziemba, L., Dibb, J. E., and Lefer, B. L.: Longpath DOAS observations of surface $\mathrm{BrO}$ at Summit, Greenland, Atmos. Chem. Phys. Discuss., 11, 6707-6736, doi:10.5194/acpd-11-6707-2011, 2011.

Swartzendruber, P., Chand, D., Jaffe, D., Smith, J., Reidmiller, 
D., Gratz, L., Keeler, G. J., Strode, S., Jaeglé, L., and Talbot, R.: The vertical distribution of mercury, CO, ozone, and aerosol scatter in the Pacific Northwest during the spring 2006 INTEX-B campaign, J. Geophys. Res., 113, D10305, doi:10.1029/2007JD009579, 2008.

Tackett, P. J., Cavender, A. E., Keil, A. D., Shepson, P. B., Bottenheim, J. W., Morin, S., Deary, J., Steffen, A., and Doerge, C.: A study of the vertical scale of halogen chemistry in the Arctic troposphere during Polar Sunrise at Barrow, Alaska, J. Geophys. Res., 112, D07306, doi:10.1029/2006JD007785, 2007.

Talbot, R., Mao, H., Scheuer, E., Dibb, J., Avery, M., Browell, E., Sachse, G., Vay, S., Blake, D., Huey, G., and Fuelberg, H.: Factors influencing the large-scale distribution of $\mathrm{Hg}^{\circ}$ in the Mexico City area and over the North Pacific, Atmos. Chem. Phys., 8, 2103-2114, doi:10.5194/acp-8-2103-2008, 2008.

Tekran: Tekran Model 2537a, Model 1130 Mercury Speciation Unit and Model 1135-p Particulate Mercury Unit, User Manuals, Toronto, Canada, 2005.

Thomas, J. L., Stutz, J., Lefer, B., Huey, L. G., Toyota, K., Dibb, J. E., and von Glasow, R.: Modeling chemistry in and above snow at Summit, Greenland - Part 1: Model description and results, Atmos. Chem. Phys., 11, 4899-4914, doi:10.5194/acp-11-48992011, 2011a.
Thomas, J. L., Stutz, J., Dibb, J. E., Huey, L. G., Liao, J., Tanner, D., Lefer, B., and von Glasow, R.: Modeling halogen chemistry in and above snow at Summit, Greenland - Part 2: Radical chemistry and sensitivity studies, Atmos. Chem. Phys. Discuss., in preparation, $2011 \mathrm{~b}$.

UNEP: Global Mercury Assessment, UNEP Chemicals, Geneva, Switzerland, 2002.

Vandal, G. M., Fitzgerald, W. F., Boutron, C. F., and Candelone, J. P.: Variations in mercury deposition to Antarctica over the past 34000 years, Nature, 362, 621-623, 1993.

Vogt, R., Sander, R., von Glasow, R., and Crutzen, P.: Iodine chemistry and its role in halogen activation and ozone loss in the marine boundary layer: A model study, J. Atmos. Chem., 32, 375395, 1999.

von Glasow, R., Sander, R., Bott, A., and Crutzen, P. J.: Modeling halogen chemistry in the marine boundary layer. 1. Cloud-free MBL, J. Geophys. Res., 107, 4341, doi:10.1029/2001JD000942, 2002. 